\title{
Üniversite Öğrencilerinin Sahte ve Kaynağı Belirsiz Facebook İletilerini Medya Okuryazarlığında Beş Anahtar Soru Çerçevesinde Sorgulama ve Paylaşma Süreçleri
}

\author{
Emel Dikbaş Torun (Dr. Öğr. Üyesi) \\ Pamukkale Üniversitesi İletişim Fakültesi \\ edikbas@gmail.com \\ Orcid: 0000000278829295
}

Başvuru Tarihi: 21.02.2019

Yayına Kabul Tarihi: 24.06.2019

Yayınlanma Tarihi: 22.07.2019

DOI: 10.17680/erciyesiletisim.530056

Dikbaș Torun, E. (2019). Üniversite Öğrencilerinin Sahte ve Kaynağı Belirsiz Facebook İletilerini Medya Okuyazarlığında Beş Anahtar Soru Çerçevesinde Sorgulama ve Paylaşma Süreçleri. Erciyes İletişim Dergisi, 6 (2), 1359-1382. DOI: 10.17680/erciyesiletisim.530056

\section{Öz}

Sosyal medya içeriğindeki çeşitlilik ve beraberinde getirdiği sürekli bilgi kirliliği sonucu, dolaşıma sokulan sahte veya kaynağı belirsiz bilgilerin güvenirlik ve doğruluğunu sorgulama gereksinimi doğmuştur. Birbirinden çok farklı çevrelerce yaygın biçimde paylaşılan sahte bir Facebook iletisi ve kaynağı belli olmayan bir kayıp ilanı iletisi; Facebook kullanıcılarınca doğruluklarının sorgulanma süreçleri ve paylaşılma durumlarının incelenmesi amaçlarıyla araştırmada kullanılmıştır. Araștırmaya toplam 116 üniversite öğrencisi katılmıștır. Katılımcılardan 46’sı Medya Okuryazarlığında Beş Anahtar Soru yaklaşımının öğretildiği ders içi uygulamalara katılarak başarı gösteren öğrencilerden oluşmaktadır. Yarı yapılandırılmış görüşmeler ile tüm öğrencilerden "Bu ileti bence ... çünkü ..., "Bu iletiyi paylaştım çünkü ..." ve "Bu iletiyi paylaşmadım çünkü ...” tümcelerini tamamlamaları istenmiştir. Araştırmada, nitel ve nicel araștırma yöntemlerinin birlikte kullanıldığı karma araştırma yaklaşımı benimsenmiştir. Araştırma sonuçları, sosyal medyada karşılaşılan iletileri sorgulamada Beş Anahtar Soru yaklaşımını kullanmanın, katılımcıların iletilerin güvenirliğini sorgulama, doğruluğundan emin olma ve iletileri anlamlandırma süreçlerini açıklamasının yanısıra bu iletileri paylaşmaya karar verme süreçlerinde anlamlı farklılık oluşturduğunu göstermektedir. Sosyal medyadaki yaygın paylaşımların kullanıcılar tarafından doğruluk derecesi sorgulanmadan paylaşıldığı görülmekle birlikte, paylaşımda sözü edilen tehlikelerin gerçekleşme olasılığına karşı bireylerin kendini garantiye alma düşüncesiyle hareket ettiği ayrıca görülmektedir.

Anahtar Kelimeler: Medya Okuryazarlığı, Sahte İçerik, Sosyal Medya, Facebook. 


\title{
University Students' Facebook Message Interpretation and Share Process in the Framework of the Five Key Questions in Media Literacy
}

\author{
Emel Dikbaş Torun (Asst. Prof. Dr.) \\ Pamukkale University Faculty of Communication \\ edikbas@gmail.com \\ Orcid: 0000000278829295
}

Date Received: 21.02.2019

Date Accepted: 24.06.2019

Date Published: 22.07.2019

DOI: 10.17680/erciyesiletisim.530056

\section{Abstract}

As a result of the diversity in social media content and the continuous pollution of information it brings, there is a need to question the reliability and accuracy of the new information circulated. A fake Facebook message and a source of loss posting, whose source is unclear; have been used in the study to investigate the questioning processes and sharing status of their accuracy by Facebook users. This research focuses on the cognitive interpretation of media literacy and the stages of analyzing the accuracy and reliability of messages with the Five Key Questions approach in Media Literacy. Two messages on social media, which have been widely shared by different circles, have been selected to analyze. 116 students both attendees and nonattendees of Media Literacy course at the Faculty of Communication participated in the study. During semi structured interviews the students were asked to complete the following sentences; "I think this message ... because ...", "I shared this message because ..." and "I did not share this message because.... In the analysis of the data, phenomenology from qualitative research patterns with content analysis and quantitative techniques were used together with mixed methods research design. The results of the research show that the widespread messages on social media are assumed correct by most of the users without questioning and it shows that the dangers mentioned in the messages are frequently shared by social media users with the idea of securing themselves against the possibility of being real.

Keywords: Media Literacy, Fraud Content, Social Media, Facebook. 


\section{Giriş}

\section{Medya Okuryazarlığı}

Medya ve teknoloji ikilisinin günümüzdeki birlikteliği yeni kavram, anlayış ve yaklaşımların ortaya çıkmasına yol açmıştır. Bu yakın birliktelik, medya ve eğitim konusunda üretilegelmiş geleneksel kavramlara yeni anlamlar yüklenerek herkesçe kabul gören çok bilindik kavramların tanımını da yeniden şekillendirmiştir. Güncellenerek yeniden anlam kazanan ve farklı türleri ortaya çıkan kavramlardan birisi okuryazarlık kavramıdır. Okuryazarlık, güncel anlamıyla artık yalnızca okuma-yazma bilmek anlamında kullanılmamaktadır (Real, 2008). Günümüz okuryazarlığl; öğrenmek, yeniden öğrenerek öğrenilen bilgilere yenilerini eklemek, var olan önbilgileri güncellemek ve neyi nasıl öğreneceğine karar vererek sürekli olarak öğrenmeye devam etmek anlamındadır. Bilgi ise, yalnızca kâğıt üzerine yazılı sözcüklerin yayılması yoluyla okunarak öğrenilebilir olmaktan çıkmış; çok çeşitli, karmaşık ve dinamik bir içeriğe dönüşmüștür. Bilginin içeriğine bağlı olarak, şekli ve paylaşılma amacı da bu doğrultuda değişim göstermeye devam etmektedir.

Medya okuryazarlığı, tanım olarak hem teknolojinin gelişimiyle okuryazarlık kavramının farklılaşma sürecini hem de bilginin geçirdiği değişimi içeren türden bir tanımlama ile açıklanabilen bütüncül bir süreçtir. Medya Okuryazarlığı Merkezi (Center for Media Literacy - CML) tarafından yayımlanan en güncel tanıma göre medya okuryazarlığı; yazılı medyadan videoya, videodan internete çeşitli yapılarda bulunan medyaya erişme, medyayı çözümleme, değerlendirme ve medya içeriği üretme becerisi için bir çerçeve sağlamaktadır (Jolls vd., 2018). Bu tanım, internet ve beraberinde gelişen yeni medya türlerinin yaşamımız ve öğrenmemiz üzerindeki etkilerini yansıtmaktadır. Medya okuryazarlığı, günümüz okuryazarlıkları arasında öğrenilmesi en gerekli olanlardan birisidir. Ancak medya okuryazarlığl, günümüzde bireysel düzeyde edinilmesi gereken bir bilişsel anlamlandırma ve çözümleme becerisi olarak değerlendirilmektedir. Medya okuryazarı bir birey; medyadaki ileti ve içeriği sorgulamaksızın doğrudan alıp aktarmayan, içerik konusunda da ezbere hareket etmeyen bireydir. Medya okuryazarlığı hem birey hem de toplumlar için çok boyutlu önem taşır (Önal, 2016: 189). Internet kullanımına bağlı olarak sosyal medya kullanımının yaygınlaşması, büyük bir bilgi kirliliğine yol açarak insanlığı sonu gelmeyen bilgi yı̆̆ınlarıyla başedebilme uğraşısıyla karşı karşıya bırakmıştır.

Medya okuryazarlığının öznesini ise toplum değil, birey oluşturmaktadır. Çünkü diğer tüm okuryazarlıklar gibi medya okuryazarlığı da bireysel bir beceri olup bilișsel yaklaşımlarla açıklanabilen bir çözümleme ve anlamlandırma sürecinin geliștirilmesi, süreç içerisinde biriktirilerek yapılandırılan kazanımlarla, her türden iletiyi çok yönlü şekilde anlamlandırılabilme becerisinin yerleşik hale getirilmesini ifade etmektedir. Bu nedenle medya okuryazarlığının asıl amacı bireyleri okuryazar yapmak, görüp duydukları iletilerin etkisi altına giren değil; medyayı eleştirel bir bakış açısıyla değerlendirip anlamlandırarak, bu iletileri kontrol edip yönlendirebilen bireyler olmalarını sağlamaktır. Medya okuryazarı bir birey, medyadaki hazır ileti ve içerikleri olduğu gibi alıp aktarmadığı gibi içerikle ilgili olarak da ezbere hareket etmez. Tam tersine, medya okuryazarlığı doğru zamanda, doğru içerikle ilgili olarak doğru soruları sorma becerisini kazanmak demektir. Masterman'a göre (2010) bireysel anlamlandırma becerileri olmaksızın bir bireyin güncel tartışmaları anlama ve bunlara katılması mümkün olmayacaktır. 


\section{Medya Okuryazarlığında Beş Anahtar Soru}

Medya okuryazarlığı konusundaki ilk kuramsal yaklaşımı geliştiren isim olan Marshall McLuhan, 1940 ve 1960lı yıllar arasındaki çalışmalarında medya ve ileti ikilisine dikkat çekmiş, medyanın kendi iletilerini oluştururken kendine özgü ve kendi düşüncelerini yansıtan bir "gramer" kullandığından bahsederek "medya iletidir" demiștir (McLuhan, 1967, s.63). İnternet ve sosyal medyanın henüz var olmadığı bir dönemde Global Köy terimini ortaya atan McLuhan, medya teknolojilerinin iletilerin yayılması ve anlaşılmasındaki etkisinin bilincinde olarak, bu etkinin önemini vurgulayan çalışmalarıyla medyanın bireylerin duygu, düşünce ve inançlarının birer uzantısı olacağını vurgulamıştır (McLuhan,1967). Medyanın özünde sorgulama gereksiniminin bulunduğunu ifade ederek bu konuyu ilk kez tartışmaya açan Masterman kitaplarında (1980; 1985) medyayı sorgulama yollarıyla ilgili ilk örnekleri televizyon ve televizyonda yayımlanan haberler üzerinden örneklendirerek vermiştir. Örneğin bir haber hazırlanıp yayımlandığında kafamızda pek çok soru uyanarak o haberin hazırlanışından amacına (süreç ve hedef), gösterilenlerin gerçekte öyle olduğunu kimlerin söylediğinden (kim ve kaynak ne?), yapılan sunumun başkaları tarafından nasıl algılandığına (etki) kadar pek çok noktanın sorgulanması gerektiğinin altını çizmiştir.

Masterman'in tartışmasını sürdüren Duncan (1987) medya okuryazarlığını sorgulamada yanıtı aranan soruları derleyerek sekiz ana kavram altında toplamış ve bu kavramları açıklama yoluna gitmiştir. Kavramsal çerçevesinin ilk kez çizildiği bu yaklaşım ile medya okuryazarlığının da kuramsal boyutları netleşmiştir (Duncan ve diğerleri, 1988). Thoman (1993) geliştirilen kavramsal çerçeveyi özetleyerek beş anahtar kavram üzerinde yoğunlaşmıştır (Tablo 1). Özünde sorgulamanın olması gerektiğini savunan Thoman, anahtar kavramların soru tümcelerine dönüştürülüp yanıtları da derinlemesine sorgulandığı takdirde medya okuryazarlığı becerisinin her yaştan öğrenen tarafından daha derinlemesine kazanılabileceğini öne sürmüştür.

Tablo 1: Medya Konusundaki Beş Düşünce

\begin{tabular}{|l|l|}
\hline 1 & Medyadaki tüm iletiler "kurgulanmıştır”. \\
\hline 2 & Medya iletileri, kendine özgü kurallar kullanan yaratıcı bir dille kurgulanmıştır. \\
\hline 3 & Farklı insanlar aynı medya iletisini farklı şekilde deneyimler. \\
\hline 4 & Medya aslında, kazanç güdüsü ile işleyen türden işlerdir. \\
\hline 5 & Medya içeyerleşik değer ve görüşlere sahiptir. \\
\hline
\end{tabular}

Medya Okuryazarlığında Beş Anahtar Soru yaklaşımının ortaya çıkışında etkili olan ve ilgili araştırmalarında genellikle vurgulanan ortak düşünceler "Beş Düşünce $^{1}$ (Five Concepts)" başlığıyla Thoman (1993) tarafından özetlenerek açıklanmıştır (Tablo 1).

Medya okuryazarlığının özelliklerine inildiğinde, medya okuryazarlığının bölümlere ayrılamayan ve kategorilere indirgenemeyen çok yönlü bilişsel, duygusal, etik ve estetik boyutlar içerdiği, bu nedenle de bütüncül bir süreç olduğu görülebilir. Bireyler, medya okuryazarlığı konusunda iyi veya zayıf okuryazarlık derecelerine göre değerlendirilebilirken, "medya cahili" veya "uzman medya okuryazarı" gibi değerlendirmeler doğru bir yaklaşım olmayacaktır (Potter, 2012: 23). Potter (2012:95) iletilerin anlamlandırılması süreci ile ilgili olarak iki boyutlu bir yaklaşımı 
benimsemiştir. $\mathrm{Bu}$ boyutlar; eşleştirme ve yapılandırmadır. İleti kaynağı belirli bir otorite olduğunda, birey yeni ileti konusu ile önbilgilerinde yer alan geçmiş bilgilerini eșleștirmektedir. Bir sonraki aşamada ise birey algıladığı iletiyi kendi ölçütlerine göre yapılandırarak yorumlama yolunu seçmektedir. Thoman (1998), medya okuryazarlığının özünde "sorgulama" olduğunu ve gördüğümüz her içerikle ilgili olarak sorular sormamız ve bu soruları ne şekilde yönelteceğimizi de bilmemiz gerektiğini belirtmektedir (Hiebert, 1999; Thoman, 1998). Jolls (2007) sorulması gereken soruları derleyip düzenleyerek Medya Okuryazarlığında Beş Anahtar Soru başlığıyla yayımlamıştır (Tablo 2). Medya Okuryazarlığı Merkezi (MOM), içerik ve iletilerin sorgulanarak anlamlandırılması konusunda aşağıda verilen temel soruların sorulmasının gerekliliğini çeşitli tartışma yazılarıyla sürekli olarak güncelleyip vurgulamaktadır (Share vd. 2019).

Tablo 2: Medya Okuryazarlığında 5 Anahtar Soru

\begin{tabular}{|l|l|}
\hline 1 & Bu iletiyi kim oluşturdu? \\
\hline 2 & İletinin kaynağı nedir/ileti nereden yönlendirimiştir? \\
\hline 3 & İleti neden paylaşımıştır? \\
\hline 4 & Bu iletide benim dikkatimi çekmek için hangi teknikler kullanılmıştır? \\
\hline 5 & Başkaları bu iletiyi benim anladığımdan farklı olarak nasıl algılıyor? \\
\hline
\end{tabular}

Tablo 2'de verilen Beş Anahtar Soru, ilk olarak Masterman'ın çalışmalarıyla başladıktan sonra yukarıda hepsine değinilen Duncan, Thoman ve Jolls'un uzun soluklu medya okuryazarlığı araştırmalarından sonra ortaya çıkan kuramsal çerçeveyi toparlayıcı niteliktedir. Bu yaklaşımda, iletiyi oluşturanın kim olduğundan başlanarak iletinin kaynağını sorgulatan, iletinin oluşturulma gerekçeleri ile dikkat çekici öğelerinden algıya doğru şekillenen bir aşamalı sorgu süreci söz konusudur. $\mathrm{Bu}$ süreçte, iletiyle ilk kez karşılaşan birey, içeriğin doğruluk ve güvenirliğini belirleyebilmek için bu soruları sorarak, soruların yanıtları doğrultusunda ileti içeriğinin güvenirlik ve doğruluk derecesini belirleyebilir. Örneğin bireyler, kim tarafından oluşturulduğu, kaynağının ne olduğu ve niçin paylaşıldığı sorularına yanıt bulunamayan türden medya içeriklerine şüpheyle yaklaşmaları gerektiği sonucuna ulaşabilirler. Okuryazarlık kavramının geleneksel anlamı dışında bilgisayar okuryazarlığı, medya okuryazarlığı, teknoloji okuryazarlığı gibi farklı şekillerde ele alındığı ve bazen de birbirinin yerine geçecek şekilde kullanıldığı görülmektedir. Medya okuryazarlığı 21. yüzyıl eğitim yaklaşımı olarak nitelendirilerek bir beceri ve iletileri anlamlandırma süreci olarak değerlendirilirken (Thoman ve Jolls, 2008), bilgiye erişme, bilginin anlamlandırılmak üzere çözümlenmesi ve iletilmesi olarak da değerlendirilmektedir (Babad, 2012). Desmond (1996) Medya okuryazarlığı eğitimini kişinin medya ile olan ilişkisinin farkındalığı, bilgi ve iletilere kolayca erişebilmesi, önbilgi düzeyi-medya-gerçek dünya ilişkisi, medyanın ticari yönü ile eleştirel ideolojik bilinci içeren çok boyutlu bir yaklaşımla ele almaktadır.

Medya okuryazarlığı, yaşamboyu devam eden bir öğrenme ve bilişsel gelişim sürecini içermektedir (Buckingham, 2003). Medya okuryazarlığının erken dönemlerden başlayarak belirli eğitim programları ve yaklaşımlarla yaşamboyu geliştirilebilecek bir beceri olarak kabul görmesi ve değerlendirilmesi, bu konuda verilmesi öngörülen eğitimin de erken yaşlarda başlayarak yetişkinlik döneminde devam ettirilmesini bir gereklilik olarak ortaya çıkarmaktadır. Bu kapsamda 
ülkemizde 2007-2008 eğitim ve öğretim yılında ilköğretim müfredatına Seçmeli Medya Okuryazarlığı Dersi eklenmiştir. Araştırmanın kuramsal temelini oluşturan Medya Okuryazarlığında Beş Anahtar Soru yaklaşımının konu edinildiği uygulamalı bir araştırmaya, özellikle de sosyal medya ve Facebook'ta paylaşılan içeriğin sorgulanmasını, içeriğin hangi aşamalara göre anlamlandırıldığını konu edinen bir araştırmaya gerek duyulmuştur. Alanyazın detaylı incelendiğinde, ülkemizde medya okuryazarlığı ile ilgili yapılan çalışmaların büyük ölçüde teorik çalışmalardan oluştuğu görülmektedir (Altun, 2014). Yapılan çalışmaların daha çok öğretmen ve öğrencilerin medya okuryazarlık düzeyleri ile medya okuryazarlığına ilişkin görüşlerinin belirlenmesiyle sınırlı kaldığı görülmüştür (Atmaca, 2016; Bacaksız 2010; Deveci ve Çengelci 2008; Elitok Kesici ve Kızılkaya, 2016; İnan, 2010).

Durak (2016) çalışmasında, sosyal medya okuryazarlığında mevcut durumu inceleyerek Türkiye'de gençlerin sosyal medya kullanım örüntülerini açıklayan bir derleme çalışması yapmıştır. Vanwynsberghe ve Verdegem (2013) çalışmasında sosyal medya okuryazarlığında içerik ve iletilerin paylaşıldığı mecraların tümünün yalnızca çevrimiçi mecralar olduğuna işaret ederek sosyal medya kullanımının daha çok teknik beceriler kapsamında değerlendirilebilecek boyutlarını incelemiş ve sosyal medya okuryazarlığını üç temel boyutta irdelemiştir. Bu boyutlar, (1) teknik (2) bilișsel ve (3) duyuşsal beceriler ile ilişkilendirilmiştir. Vanwynsberghe vd. sonraki çalışmasında bu yaklaşımlarını geliştirerek araştırmalarını derinleștirmiş ve 2014 yılındaki araștırmalarında medya okuryazarlığı becerilerini eleştirel, yaratıcı, stratejik, analitik ve bilgi becerileri ile birleştirerek açıklamışlardır. Araştırmalarının sonucunda, sosyal medya okuryazarı öğrencilerin iletileri hem teknik hem de analitik olarak çözümleyebilme becerilerine aynı anda sahip olan bireyler olduklarının altını çizmişlerdir. Bu araştırmada da benzer şekilde bireylerin iletileri anlamlandırma becerilerine odaklanılmakta ve bu becerileri kullandıracak sorgulama yaklaşımlarının incelenmesi amaçlanmaktadır.

Sosyal medya okuryazarlığında iletilerin tümünün çevrimiçi olması, sosyal medya okuryazarlığını medya okuryazarlığından tümüyle ayrışan farklı bir araştırma alanı yapmaz ancak medya okuryazarlığının güncel bir dalı olarak sosyal medya okuryazarlığı kavramını tartışmaya açabilir. Sosyal medyada paylaşılan içeriğin üretimi, bilinçli paylaşım yapma ve sosyal medyada paylaşılan içerikleri anlamlandırabilme becerilerinin; yeni medya okuryazarlığı, dijital okuryazarlıklar, 21. yüzyıl okuryazarlıkları ve sosyal medya okuryazarlığı şeklinde farklı isimlendirmelerle güncel medya okuryazarlığı araştırmalarında detaylandırıldığı görülmektedir. (Babad 2012, Vanwynsberghe vd. 2014, Potter 2008, Jenkins, 2006). İletilerin paylaşıldığı mecralar ve iletilerin içeriği sürekli olarak değişmekte, başedilmesi gereken bilgi yığınları ve içeriğin miktarı da gün geçtikçe artmaktadır. Büyük bilgi yığınları arasından doğru ve güvenilir olanları seçip ayıklamada, içeriğin yayılmasında daha pratik ve uygulanabilirliği yüksek, kolay anlaşılır yaklaşımlara kişilerin medya okuryazarlığ gereksinim vardır. Bu yaklaşımların geliştirebilmesinde ise bireylerin hangi süreçleri benimseyerek iletileri anlamlandırdığının bilinmesi yol gösterici olabilir. Medya okuryazarlığı eğitiminin etkilerini sosyal medya kullanımı ve yeni dijital mecraları da kapsayacak şekilde hem uygulamalı olarak hem de nitel/nicel yaklaşımların birlikte kullanıldığı karma yaklaşımlarla açıklayabilen çok yönlü ve derinlemesine araştırmalara gerek vardır. 


\section{Amaç, Önem ve Problem Durumu}

Sosyal medyanın gücü ve yaygınlığı dikkate alındığında medya okuryazarlığının artık sosyal mecraları bilinçli kullanmada son derece gerekli ve önemli bir beceri olduğu görülebilir. Dolaşımdaki bilgi yığınları arasından doğru ve güvenilir olanları seçip belirleyebilmek ise çoğu insan için sorun yaratan ciddi bir güçlüktür. Yapılacak çalışmalarda özellikle sosyal medyadaki içeriğin sorgulanıp yorumlanması ve paylașım davranışına karar verme sürecinde medya okuryazarlığı eğitiminin etkisinin araştırılması önemlidir.

Medya Okuryazarlığında Beş Anahtar Soru yaklaşımı, ilk kez karşılaşılan bir içeriğe öncelikle şüphe ve sorgulayıcı bir bakış açısı ile yaklaşma bilincini kullanıcılara öğretmesi bakımından önem taşımaktadır. Yaklaşımın ilerleyen aşamaları, kullanıcıların içeriğin kim tarafından hangi amaçla oluşturulduğu ve niçin yaygın hale getirilmek istendiği konusunda kullanıcılara doğru soruları sorduran bir süreci işletmektedir. İște bu noktada, kullanıcıların ne tür sorgulama süreçlerini benimseyerek sosyal medya içeriklerinin güvenirliğini kendilerince test ettiklerinin bilinmesi önemlidir. Karşılaşılan içeriğin işaret ettiği tehlikelerin gerçekten var olup olmadığının bilincinde olunması ve ona göre davranarak ilgili içeriklerin paylaşılması yoluyla kısa sürede hızla yayılmasına katkı koyulması konusunda bilinçli hareket etmeyi bilen sosyal medya kullanıcılarının varlığı günümüzde daha çok gereklidir.

Örneğin sosyal medyada karşılaşılan bir kayıp ilanının gerçekte yalnızca bir kayıp ilanından ibaret olmayabileceği, ilana konu edilen kişinin kötü amaçlı kimselerce aranmakta olabileceği olasılıklarının düşünülerek, bu türden iletilerin paylaşımına dikkatle karar verilmesi sosyal medya kullanıcıları açısından önemli bir beceridir. Ek olarak, sahte ileti, viral paylaşım ve yalan haberler, dolandırıcılıktan eğlenceye, sosyal deneyden viral paylaşımları yaygınlaştırmaya kadar pek çok farklı amaçla sosyal medyada dolaşıma sokulmaktadır. Sosyal medyada hem kirlilik oluşturan hem de kullanıcıların diğer kullanıcılara ilişkin görüşünü etkileyen bu türden sahte içeriğin yoğun bir şekilde paylaşılıyor olması sosyal medya kullanımındaki bilinçsizliğe işaret etmektedir. İletileri paylaşanlar açısından olumsuz sonuçları da olabilecek bu tür iletilerin paylaşımının ve yaygınlaşmasının önüne geçmek yalnızca kullanıcıların bilinçli paylaşım yapmalarının sağlanmasıyla mümkün olabilecektir. Bu nedenle, kullanıcıların iletileri paylaşırken hangi sorgulama süreçlerine başvurdukları, iletilerin doğruluğundan şüphe duyup duymadıkları, iletilerde yer alan tehditkâr içerik ve kendilerini kötü etkileyebileceğini söyleyen ifadeler karşısında, iletileri nasıl anlamlandırdıklarının bilinmesi sosyal medyada bilinçli paylaşımlar yapmayı sağlayabilme bakımından önemlidir.

Sosyal medya kullanıcılarının bu içerik karşısında hangi bilişsel anlamlandırma süreçleriyle iletileri sorguladıklarının bilinmesi, kullanıcılara doğru sorgulama yaklaşımlarının nasıl öğretilebileceğinin belirlenmesi açısından önemlidir. $\mathrm{Bu}$ nedenle, bu araştırmada öncelikle kullanıcıların iletileri nasıl sorguladıklarının araştırılarak ortaya çıkarılması ve Medya Okuryazarlığında Beş Anahtar Soru yaklaşımına göre iletileri sorgulayan bireylerin sahte ve kaynağı belirsiz iletileri sorgulamada ne ölçüde bilinçli davrandıklarının belirlenmesi amaçlanmıştır. Bu sayede, bir yöntem olarak Medya Okuryazarlığında Beş Anahtar Soru yaklaşımının sosyal medyada bilinçli paylaşımlar yapma becerisine sahip medya okuryazarı bireyler yetiştirebilmedeki pratik katkısı belirlenebilecek, yöntemin oluşturduğu fark ortaya konabilecektir. 
Araştırmanın amacı, sosyal medyadaki yaygın ve sıkça paylaşılan iletilerin paylaşılma gerekçeleri ile iletilerin doğruluk ve güvenirliğinin sorgulanması durumlarını Medya Okuryazarlığında Beş Anahtar Soru çerçevesinde araştırmaktır. Ayrıca bu iletilerin yayılmasında, medya okuryazarlığı eğitimi almış (Medya Okuryazarlığında Beş Anahtar Soru yaklaşımını kullanıp uygulayabilen) bireyler ile almamış olan bireyler arasında iletileri paylaşma kararına göre farklılık olup olmadığının incelenmesi hedeflenmektedir. Bu sayede medya okuryazarlı̆̆ eğitiminin kişilerin medyadaki iletileri sorgulama ve anlamlandırma düzeyleri ile sorgulama beceri düzeyleri arasındaki farklılıklar ortaya konabilecektir.

Sosyal medyada kullanıcıların, eğitim ve kültür düzeylerine bağlı olmaksızın sahte içerik ve iletileri gerçek oldukları düşüncesiyle, içeriğin doğruluğuna inanarak ve içerikte yazılanlara güven duyarak paylaştıkları görülmektedir. Bu noktada iletileri paylaşmaya karar verirken kullanıcıların bu iletileri genellikle sorgulamadıkları veya iletilerin sahte olduğunun farkında olmadan bunu yaptıkları görülmektedir. $\mathrm{Bu}$ çalışma, Medya Okuryazarlığında Beş Anahtar Soru yaklaşımıyla sosyal medyadaki ileti ve içerikleri sorgulamanın, sosyal medyayı bilinçli kullanmadaki etkisini ortaya koyarak, sosyal medya iletilerini sorgulama becerisine sahip olan ve olmayan bireyler arasındaki farklılıkları karşılaștırmalı olarak göstermeyi hedeflemektedir. Araştırmanın problem durumunu açıklayabilecek araştırma soruları aşağıdaki gibi belirlenmiştir:

Katılımcıların, sahte ve kaynağı belirsiz iletileri anlamlandırma ve sosyal medyada paylaşma kararı süreçleri, Medya Okuryazarlığında Beş Anahtar Soru yaklaşımının aşamalarına göre nasıl oluşmaktadır?

Katılımcıların iletileri sorgulama ve anlamlandırma süreci sonrasında iletileri paylaşma/paylaşmama karar durumları daha önce Medya Okuryazarlığında Beș Anahtar Soru yaklaşımı eğitimi almış olma bakımından farklılık göstermekte midir?

Verilerin çözümlenmesinde birinci araştırma sorusuna (1) İçerik Çözümlemesi, (2) Tematik Çözümleme ve (3) Olgubilim yoluyla nitel yaklaşımla yanıt aranacaktır. İkinci araştırma sorusuna ise Farkın Anlamlılığı istatistiksel çözümlemesi ile nicel yaklaşımla yanıt aranacaktır.

\section{Yöntem}

$\mathrm{Bu}$ araştırma karma araştırma deseniyle yapılmıștır. Nitel araştırma yaklaşımı, derinlemesine çözümleme ve var olan durum ve olguların algı boyutunu açıklamadaki üstünlüğü ile ön plana çıkmaktadır. Çalışmada belirlenen değişkenler (Bağımlı değişken: İletileri paylaşma durumu; bağımsız değişkenler: Medya okuryazarlığı dersi almış ve medya okuryazarlığı dersini almamış olmak) arasındaki ilişkiyi açıklamada ise nicel araştırma yaklaşımından yararlanılmıştır. Araştırmanın kuramsal temelini MOM tarafından geliştirilen Medya Okuryazarlığında Beş Anahtar Soru Yaklaşımı oluşturmaktadır. Medya iletilerinin içeriğini anlamlandırma sürecine ilişkin beș aşamalı bir sorgulama tekniğini anlatan bu teknik, eleștirel düşünme becerisinin bir göstergesi sayllan sorgulama ve çok yönlü düşünebilme becerilerini içermektedir.

Eleştirel Medya Okuryazarlığı eğitiminin temel becerisi olarak günümüzün sorgulayan, eleştirel düşünebilen ve anlamlandırma becerisine sahip medya okuryazarı bireylerinin yetiștirilmesinde Medya Okuryazarlığında Beş Anahtar 
Soru yaklaşımı önemli yer tutan temel bir kazanım olarak Kanada ve Amerika Birleşik Devletleri gibi dünyanın gelişmiş ülkelerinin öğretim programlarındaki yerini almıștır.

Sözkonusu ülkelerde, Medya Okuryazarlığında Beş Anahtar Soru yaklaşımını geliştiren Jolls ve Thoman'ın “Literacy for the 21st Century: An Overview and Orientation Guide to Media Literacy Education" adlı kitabı (Thoman ve Jolls, 2008) medya okuryazarlığı eğitiminde öğretmen el kitabı olarak müfredatta kullanılmaktadır.

Çalışmanın nitel araştırma basamağında olgubilim (fenomenoloji) yöntemi kullanılmıştır. Olgubilim çalışmaları, katılımcılar tarafından tanımlanan bir olgu hakkında insan deneyimlerini açıklamak için başvurulan bir açıklayıcı çözümleme yöntemidir (Creswell, 2007). Cresswell'e göre (2007: 57) olgubilim yaklaşımını anlayabilmek için öncelikle onun altında yatan felsefeyi de anlamak gereklidir. Çevremizdeki her şey, kısacası dünya, bizim kendi algılarımızdır ve anlam oluşturduğumuz var olan bilgilerimizi, bu algılarımız geniş bir şekilde etkiler. Olgubilim, bireysel anlamlandırmaların daha geniş sosyal bağlamlarda gerçekleştiğini kabul etmektedir (Patton, 2002: 104).

Bireysel açıdan bakıldığında anlamı tam olarak kavranamamış olguları araştırıp açıklamanın hedeflendiği çalışmalarda, olgubilim uygun bir araştırma yöntemi olarak karşımıza çıkmaktadır (Şimşek ve Yıldırım, 2005: 43). Bu bakımdan, bireylerin yaşadığı deneyimleri anlamlandırmaya çalışan olgubilim yaklaşımı; bir felsefe veya süreç, kalıp ve anlam ilişkileri geliştirebilmek için geniş kapsamlı odaklanma yoluyla olguları çözümlemeyi içeren bir araştırma yöntemi olarak nitelendirilebilir (Moustakas 1994; Willig, 2008).

$\mathrm{Bu}$ araştırmada olgubilim yaklaşımının seçilmesinin nedeni; sosyal medyadaki sahte ve kaynağı belirsiz iletilerin paylaşımına ilişkin olguların nasıl algılandığının, katılımcıların gerçek deneyimleri ile derinlemesine anlaşılmaya çalışılmasıdır. Olgubilim çalışmaları, bize tam anlamıyla yabancı gelmeyen, aynı zamanda anlamını da tam olarak kavrayamadığımız olguları araştırmayı amaçlamaktadır. İletileri sorgulayıp paylaşırken kullanılması gereken ölçütler konusunda bireylerde tam olarak bir kavram bütünlügünün bulunmayışı, katılımcıların yaşadıkları deneyimler ve bu deneyimlerin zengin anlatımlarını yapabilmek için çalışmanın nitel yaklaşımını olgubilim oluşturmuştur. Araştırmanın nitel yaklaşım boyutunda, tematik çözümleme yoluyla gerçekleşen betimsel olgubilim yöntemi kullanılmıştır. Araștırmanın nicel yaklaşım boyutunda ise toplanan verilerin katılımcı gruplar bakımından farklılığı incelenmiştir.

\section{Katılımcılar}

Araștırmanın katılımcıları bir devlet üniversitesinin İletişim Fakültesi öğrencileri arasından seçilmiştir. 2018-2019 eğitim öğretim yılı itibarıyla, İletişim Fakültesi 1, 2, 3 ve 4. sınıflarına devam eden toplam 116 öğrenci elverişli örnekleme yaklaşımıyla gönüllü olarak araştırmaya katılmak üzere seçilmiştir. Katılımcıların \%60’ı (n=70) lisans düzeyinde Medya Okuryazarlığı dersini henüz almamıș, \%40’ı ise almıștır ( $n=46, N=116)$. Katılımcılardan, Medya Okuryazarlığı dersini almış olanlar; Medya Okuryazarlığında Beş Anahtar Soru yaklaşımı konusundaki ders içi etkinliklere katılarak derse düzenli devam eden ve dönem sonu akademik not ortalaması 
100 puan üzerinden 80 ve üzerinde olan öğrenciler arasından rastgele örneklem seçimiyle belirlenmiștir. Dolayısıyla, Medya Okuryazarlığı dersinin beklenen kazanımlarını edinmiş olan öğrenciler araştırmaya katılmıştır. Ders içi etkinlikler, bu araştırmaya konu olan sahte ve kaynağı belirsiz sosyal medya içeriklerinin sorgulandığı ve doğruluğunun teyit edildiği türden etkinlikler olduğundan, medya okuryazarlığı dersini alan öğrencileri ifade eden katılımcı öğrenciler, sahte iletilerle karşılaştıklarında o iletilerin sahteliğini sorgulama becerisine sahip öğrencilerdir.

\section{Veri Toplama Araçları}

Araştırmanın nitel basamağı için yarı yapılandırılmış görüşme formu aracılığıyla veri toplanmıştır. Hazırlanan yarı yapılandırılmış form, çevrimiçi olarak düzenlenip sisteme yüklenerek yüzyüze görüşmeler sırasında doğrudan veri girişinde kullanılmak üzere araştırmacı tarafından yayımlanarak kaydedilmiștir. Formun hazırlanıp yayımlanmasında Qualtrics ölçme aracı geliştirme ve paylaşım platformu kullanılmış, araştırmacı görüşmeler sırasında aldığı yanıtları doğrudan sisteme girerek kâğıt-kalem tabanlı ve veri aktarımı zaman alan geleneksel veri toplama tekniğine yenilikçi ve tasarruflu bir yaklaşım getirmiștir.

Veriler bu platform üzerinden toplanarak araștırmacının veritabanına doğrudan aktarılmıştır. Resim 1'de veri girişinde kullanılan Qualtrics ortamından bir görsel verilmektedir. Görüşmede, demografik özellikler, kısa yanıtlı sorular, çoktan seçmeli sorular ve metin girişiyle yanıtlanabilen açık uçlu sorular kullanılmıştır.

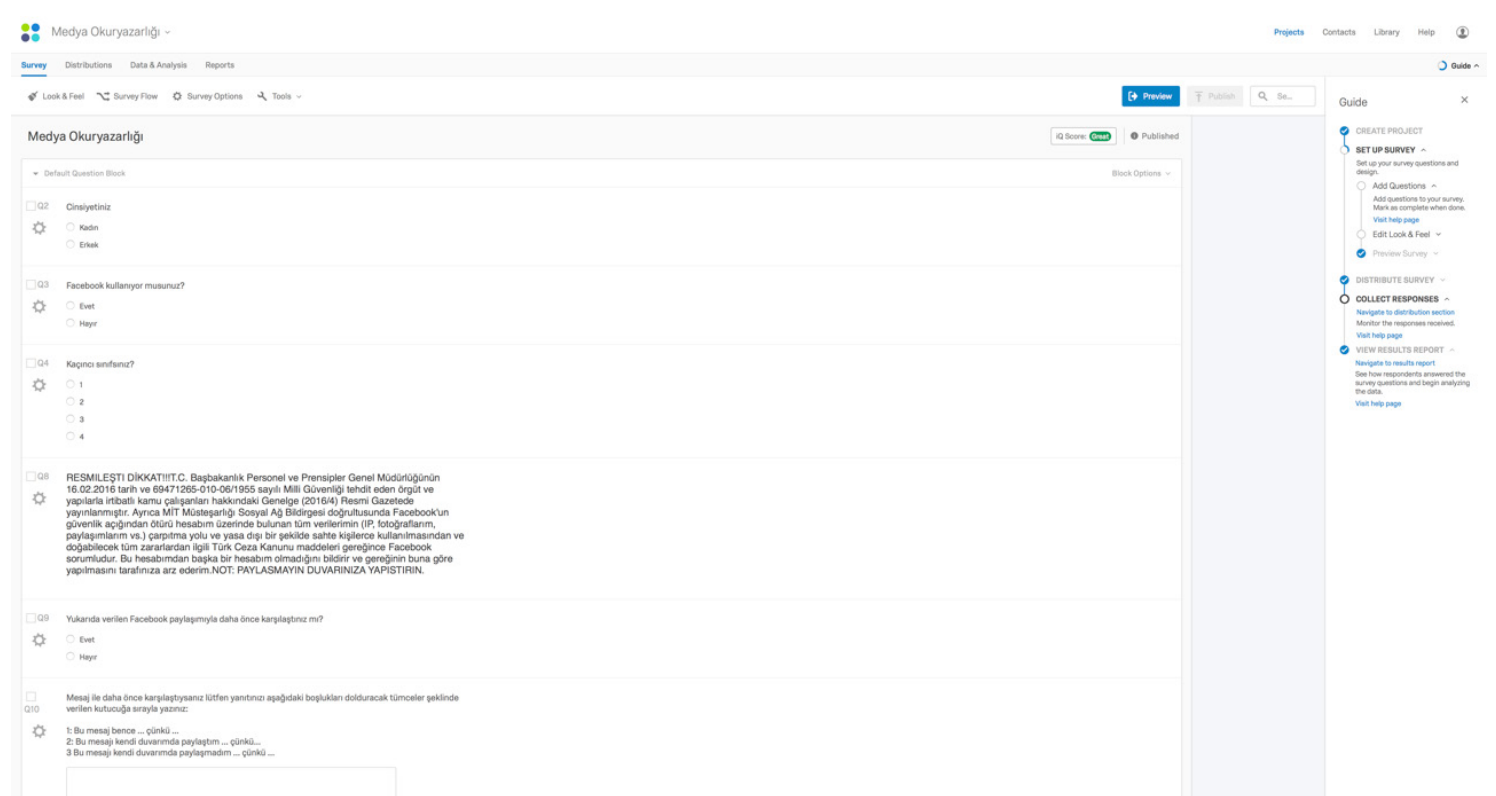

Resim 1: Yarı Yapılandırılmış Görüşme Formunun Qualtrics Platformundaki Arayüzü

Araştırmada incelenmesi ve Facebook'ta paylaşılmalarına iliş̧in çıkarımlar yapılması hedeflenen iki yaygın sosyal medya iletisi olarak aşağıda gösterilen (1) Uyarı İletisi niteliğindeki uydurma ileti ve (2) Kayıp İlanı seçilmiştir (Bkz. Resim 2 ve 3). 


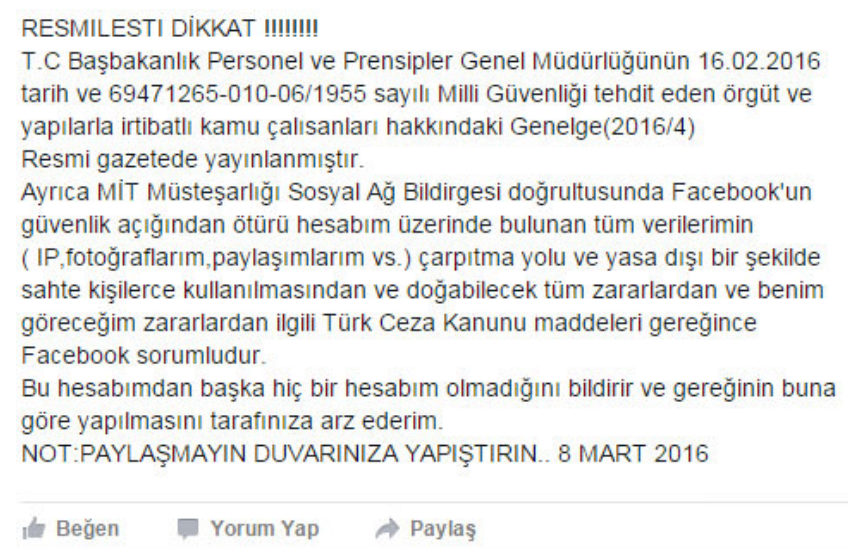

Resim 2: Uyarı İletisi Niteliğindeki Yaygın Sosyal Medya Paylaşımı

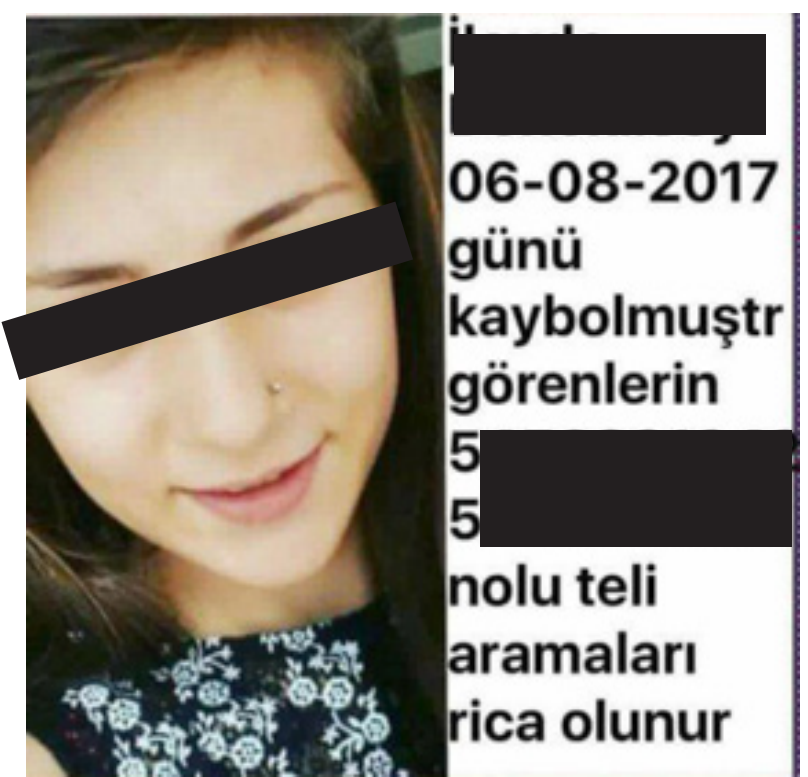

Resim 3: Kayıp İlanı Niteliğindeki Sosyal Medya Paylaşımı

Sosyal medya iletilerinin seçilmesi sürecinde, araştırmanın yapıldığı devlet üniversitesinde görev yapan iki ayrı uzmanın ortak görüşüne ${ }^{2}$ bağlı olarak ilgili alanyazından hareketle, araștırmacı tarafından aşağıda verilen "Sosyal Medyadan Paylaşım Seçme Ölçütleri" geliştirilmiştir. İletilerin, araştırmanın parçası olmak üzere sosyal medyadaki içerikyığınları arasından ayıklanarak seçilmesinde aşağıdaki özellikler belirleyici özellikler olarak kullanılmıștır:

1. İncelenmek üzere seçilecek iletinin sosyal medyadaki paylaşılma sıklığı ve yaygınlığl,

2. İletinin bir süre sonra küçük güncellemelerle sosyal medyada tekrar dolaşıma girmesi,

3. İleti yapısının sosyal medya kullanıcılarında algı, kaygı veya tepkisellik olușturabilmesi,

4. İletinin kullanıcılar üzerinde doğrudan "ne olur ne olmaz" veya "yardım etmeliyim" vb. davranışlar oluşturabilmedeki etki gücü,

5. İletinin sosyal medyada çok sayıda kullanıcı tarafından dikkate alınarak gündem oluşturabilme düzeyi,

6. İletinin özgünlüğü 
Yarı yapılandırılmış görüşme formunun ilk bölümünde katılımcıların cinsiyeti, Facebook kullanma durumları ile fakültede devam ettikleri sınıf düzeyi gibi demografik özelliklerine yer verilmiştir.

Yarı yapılandırılmış görüşme formunun ikinci bölümünde ileti içeriği verilerek katılımcılara iletilerle ilgili açık uçlu sorular yöneltilmiştir. Seçilen her bir ileti için katılımcıların iletilerle daha önce karşılaşıp karşılaşmama durumlarına göre "çünkü..." sözcüğü ile bağlanan ilişkisel gerekçeli boşluk doldurma tümcelerine yer verilerek katılımcılardan tümceleri tamamlayıp istedikleri şekilde yazmaları istenmiştir.

(1) İletiler ile daha önce karşılaşmış olan katılımcılar için soru seti:

Bu ileti bence... çünkü...

Bu iletiyi paylaştım çünkü ...

Bu iletiyi paylaşmadım çünkü ...

(2) İletiler ile daha önce karşılaşmamış olan katılımcılar için soru seti:

Bu ileti bence... çünkü...

Bu iletiyi paylaşırım çünkü ...

Bu iletiyi paylaşmam çünkü ...

Yarı yapılandırılmış görüşme formunun son sorusu olarak katılımcılara daha önce üniversite düzeyinde Medya Okuryazarlığı dersi alıp almadıkları sorulmuştur. Evet-hayır sorusu şeklinde yöneltilen bu sorunun yöneltilmesindeki amaç, Medya Okuryazarlığında Beş Anahtar Soru yaklaşımını bilen katılımcılar ile bu yaklaşımı henüz öğrenmemiş olanların paylaşım davranışları arasındaki farkı belirlemektir.

\section{Verilerin Çözümlenmesi}

Yarı yapılandırılmış görüşme formu aracılığıyla toplanan veriler, nitel yaklaşım aşamasında içerik çözümlemesi, tematik çözümleme ve olgubilim; nicel yaklaşım aşamasında ise farkın anlamlılığı testleri kullanılarak karma araştırma deseni yaklaşımına uygun olarak çözümlenmiştir. Verilerin çözümlenmesinde MAXQDA 12 ve SPSS 22 yazılımları kullanılmış, verilerin doğrudan aktarımında Qualtrics platformu aracılığıyla oluşturulan veri tablolarından yararlanılmıştır.

Kodlama: Çalışmanın nitel veri çözümleme yöntemi olarak Giorgi'nin (1997) tanımlayıcı olgubilimde kullandığı içerik çözümlemesi yöntemi dört aşamalı olarak uygulanmıştır. Bu aşamalar (1) Kodlama, (2) Tema Oluşturma, (3) Kod ve temaları düzenleme ve (4) Bulguların yorumlanması şeklinde sıralı olarak gerçekleştirilmiştir. Çalışmada elde dilen tüm sözel veriler sözcük sözcük çözümlenmiş ve olguya ilișkin kavramlar tek tek incelenmiștir. Kodlama süreci boyunca benzer kod ve alt kodlar, uygun temalarda birleştirilerek ilişkilendirilmiş ve gruplandırılmıştır. Nitel çözümlemeye kodlama ile başlanarak bütüncül anlam yakalanmış ve belirli kavramlar üretilmiştir. Kodlar, verilere ilişkin yönlendirici etiketler olarak kullanılır ve araştırmacılar tarafından kod dizileri farklı ve özgün isimlerle adlandırılmaktadır (Keller, 1995).

Geçerlik ve güvenirlik: Yarı yapılandırılmış görüşmelerde katılımcıların yalnızca kendi düşüncelerini yansitabilmeleri için örnek olarak verilen medya iletilerinin doğruluğu ve içeriği konularında katılımcıları yönlendirici herhangi bir bilgi ve ipucunun verilmemesine özen gösterilmiştir. Araştırmanın geçerliliği açısından, katılımcıların oluşturduğu gerekçe, açıklama ve yanıtlara doğrudan yer verilmiş 
ve elde edilen katılımcı görüşlerinden yola çıkılarak bulgular yorumlanmıştır. Sonuçların denenerek onaylanması yoluyla araştırma bulguları doğrulanmaktadır (Merriam, 1998). Doğrulama için farklı kodlayıcılar tarafından aynı veri setinin kodlanması gerekir. Farklı kodlayıcılar tarafından kodlanan veri setlerindeki kodlar arası benzerlik oranının hesaplanması gerekir. Bu benzerlik oranı nitel araştırmaların güvenirliğini belirlemektedir (Poggenpoel ve Myburgh, 2003). Araștırmanın kodlayıcılar arası güvenirliğini sağlamak üzere kategorilere ayrılan kodlar iki uzmanın görüşüne sunulmuş ve tutarlılık incelemesi yapılmıştır.

Güvenirlik Katsayısı = (Görüş Birliği/Terim Sayısı) / (Görüş Birliği/Terim Sayısı + Görüş Ayrılığı / Terim Sayısı) X 100 formülü kullanılarak tutarlılık hesaplanmıştır (Miles ve Huberman, 1994; Patton, 2002).

Hesaplama sonucuna göre uzmanların ve araştırmacının çözümlemesi arasındaki uyum değeri 0,94 olarak hesaplanmış ve bu değerin 0.80 değerinin üzerinde olduğu görülerek araştırma bulguları için gerekli güvenirliğin sağlandığı belirlenmiştir.

Verilerin yorumlanması: Araştırmada belirtilen bu aşamaların gerçekleştirilmesinden sonra oluşturulan kod, kategori ve açlklamalar şekil ve tablolar halinde sunulmuş ve yorumlanmıștır. Araştırmada aktarılabilirliği sağlamak için; katılımcı bilgileri, veri toplama süreci ve sınırlılıkların açıklanması önerilmektedir (Shenton, 2004, s.70). Bu araștırmada aktarılabilirliği sağlamak için; araştırma deseni ve neden bu desenin tercih edildiği, çalışma grubu ve demografik özellikleri, veri toplama süreci ve verilerin çözümlenmesi ayrıntılı olarak açıklanmıştır. Araștırma bulguları sunulurken katılımcıların belirttikleri görüşlerden yapılan alıntılara doğrudan yer verilmiştir.

\section{Bulgu ve Yorumlar}

İletişim Fakültesine devam eden 116 katılımcının (82 Kadın, 34 Erkek) demografik özelliklerine göre dağılımları ve devam ettikleri sınıf Tablo 3'te verilmektedir.

Tablo 3: Katılımcıların İletişim Fakültesindeki Sınıf Düzeyine Göre Dağılımları

\begin{tabular}{|l|c|c|}
\hline Fakültede kayıtı olunan sınıf & $\mathbf{f}$ & $\mathbf{\%}$ \\
\hline 1 & 36 & 31,03 \\
\hline 2 & 28 & 24,13 \\
\hline 3 & 38 & 32,75 \\
\hline 4 & 14 & 12,06 \\
\hline Toplam & 116 & 100 \\
\hline
\end{tabular}

Katılımcılar arasından Medya Okuryazarlığı dersini alan ve Medya Okuryazarlığında Beş Anahtar Soru yaklaşımı uygulamalarına katılarak başarıyla tamamlayan öğrencilerden 46'sı 2, 3 ve 4. sınıf öğrencileri arasından seçilen öğrencilerden oluşmaktadır. Medya Okuryazarlığı dersi 2. Sınıf müfredatında seçmeli ders olarak okutulmaktadır.

Tablo 4: Facebook Kullanma Durumu

\begin{tabular}{|l|c|c|}
\hline & f & \% \\
\hline Kullanıyorum & 92 & 79,31 \\
\hline Kullanmıyorum (Önceden kullanmış) & 24 & 20,69 \\
\hline Toplam & 116 & 100 \\
\hline
\end{tabular}


Katılımcıların \%79,31'i düzenli olarak Facebook kullandıklarını bildirmişlerdir. Facebook kullanmayan \%20,69'luk kesim ise daha önce Facebook kullandıklarını ancak çeşitli sebeplerle kısa süre önce Facebook kullanmayı bırakarak Instagram vb. diğer sosyal medya araçlarına geçiş yaptıklarını, artık etkin şekilde Facebook kullanmadıklarını belirtmişlerdir. $\mathrm{Bu}$ bulgu araştırmaya katılan öğrencilerin yaşamları boyunca belli bir süre etkin olarak mutlaka Facebook kullandıklarını göstermektedir. Katılımcıların sosyal medyada (Facebook) araştırma için seçilen iletilerle daha önce karşılaşıp karşılaşmama durumları Tablo 5'te verilmektedir.

Tablo 5: Facebook Kullanmaya Devam Eden Katılımcıların Seçilen Sosyal Medya İletileri ile Daha Önce Karşılașma Durumları

\begin{tabular}{|l|c|c|c|c|}
\hline \multirow{2}{*}{} & \multicolumn{2}{|c|}{ İeti 1: Uyarı İletisi } & \multicolumn{2}{c|}{ İeti 2: Kayıp İlanı } \\
\cline { 2 - 5 } & $\mathbf{f}$ & $\mathbf{\%}$ & $\mathbf{f}$ & \% \\
\hline Karşılaştım & 62 & 67,39 & 28 & 30,43 \\
\hline Karşılaşmadım & 30 & 33,61 & 64 & 69,57 \\
\hline Toplam & 92 & 100 & 92 & 100 \\
\hline
\end{tabular}

Katılımcıların iletilerle daha önce karşılaşma durumları incelendiğinde, "Resmilești Dikkat” başlıklı iletiyle karşılaşma oranının yüzde 67 olduğu görülmektedir. Bu oran katılımcıların kayıp ilanı ile karşılaşma oranından daha yüksektir. Araştırma katılan toplam 116 öğrenciden 62'si ilk ileti ile, yüzde 30’u ise ikinci iletiyle daha önce karşılaşmıştır. Tablo 6 incelendiğinde katılımcıların iletileri paylaşma davranışları ile karşılaşmaları halinde verecekleri paylaşma veya paylaşmama kararına ilişkin yüzdeler gösterilmektedir.

Tablo 6: Illetilerle Karşılama Durumu ve İletileri Paylaşma Dağılımı

\begin{tabular}{|l|l|c|c|c|c|}
\hline \multicolumn{2}{|c|}{} & \multicolumn{2}{c|}{ İleti 1: Uyarı İletisi } & \multicolumn{2}{c|}{ İeti 2: Kayıp İlanı } \\
\cline { 3 - 6 } \multicolumn{2}{|c|}{} & $\mathbf{f}$ & $\mathbf{\%}$ & $\mathbf{f}$ & $\%$ \\
\hline \multirow{2}{*}{ Karşılaştım } & Paylaştım & 24 & 38,70 & 20 & 71,42 \\
\cline { 2 - 6 } & Paylaşmadım & 38 & 61,29 & 8 & 28,58 \\
\hline \multirow{2}{*}{ Karşılaşmadım } & Paylaşıım & 12 & 40 & 35 & 54,68 \\
\cline { 2 - 6 } & Paylaşmam & 18 & 60 & 29 & 45,32 \\
\hline
\end{tabular}

Tablo 6 incelendiğinde katılımcıların yaklaşık yüzde 39'unun sözkonusu "Resmileşti Dikkat" iletisini paylaştıkları görülmektedir. Bu yüzdeye karşılık bu iletiyle karşılaştığ halde iletiyi paylaşma gereği duymama yüzdeleri daha yüksektir (\%61). Tersi şekilde bu durum, kayıp ilanı sözkonusu olduğunda ilanın paylaşılması eğilimi yönünde gerçekleşmektedir (\%71). Resmileşti Dikkat iletisi incelendiğinde iletide yer verilen resmi kurum ve kuruluşların gerek resmiyetteki varlıkları gerekse görev tanımları bağlamında bu tür bir paylaşımda bulunmayacakları açıktır. İletinin doğru olmadığını anlamak için iletiye şüpheyle yaklaşıp küçük çaplı birkaç sorgulama sonucunda iletinin kasıtlı olarak dolaşıma açılmış sahte bir paylaşım olduğu kolayca görülebilmektedir. Ayrıca, Facebook kullanım amaçları ve bu sosyal medya aracının dinamikleri gereği bu türden paylaşımların kullanıcıların kendi duvarlarında görünür hale getirilmesi işlevsiz bir çabadır. "Ama bakın ben bunu kendi duvarımda paylaşıp sorumluluğu üzerimden atmışım, gerisini bilemem” şeklinde bir yaklaşımın çok da mantıklı olmadığı açıktır. Tüm Facebook kullanıcıları, paylaşılan içeriğin belirlenen hak ve kurallar çerçevesinde kaldığ sürece kişisel paylaşımdan ibaret olduğunun farkındadır. 
Araștırmanın nitel veri setini oluşturan yanıtlar çok uzun ve 116 kişilik olduğundan buraya tümünü almak mümkün olmamıștır. Yanıtların genelini temsil edebilecek türden açıklayıcı yanıtlar buradaki bulguları açıklamak üzere seçilmiştir.

Araștırmaya katılan ve lisans düzeyinde Medya Okuryazarlığı dersi almış olan K48, K42 ve K89 ile dersi henüz almayan K78, K102 ve K93 şunları söylemiştir³:

K48: Mesajı duvarımda paylaşmadım çünkü inanmadım.

K42: Bu mesajı paylaşmam. Buna hemen inanıp bunu duvarında paylaşan kişi telefon dolandırıcısına da kolayca inanır, çünkü sorgulamıyor.

K89: Bu mesajı kendi duvarımda paylaşmam çünkü gerçekliği ve ikna kapasitesi düşük.

K78: Paylaşmadım çünkü bu tarz insanı galeyana getiren mesajların dönem dönem sosyal medyada döndügünden haberdarım. Buna destek olmak istemiyorum

K102: Bu mesajı kendi duvarımda paylaştım çünkü güvenliğimden endişe duydum

K93: Bu mesaj bence daha önce de benzerleri paylaşılan boş ve ortaliğı karıştırmak amacıyla yapılan mesajlardandır. Bu mesajı paylaşmam çünkü sahte olduğunu ve yaşlı insanları hedeflediğini biliyorum.

Kayıp Aranıyor ilanları ise sosyal medyadaki en yaygın ve en kolay suiistimal edilebilen paylaşımlar arasındadır. Bir insana yardım etmeyi veya kayıp bir kişinin bulunmasına katkıda bulunmayı herkes ister ve elinden geleni yapma çabasına girer. Fakat sosyal medyadaki paylaşımlar gerek kaynağının bilinmemesi gerekse örtük amaçlar taşıyabilme olasılığına karşı dikkatle irdelenmelidir. Örneğin Medya Okuryazarlığı dersini almış olan bir katılımcl, K13 bu konudaki iletiyi paylaşmama kararını gerekçelendirirken çok farklı bir açıdan konuyu derinlemesine değerlendirebilmiş; K40 ise iletinin doğru ya da yanlışlığından ziyade konuyu mantık çerçevesinde değerlendirmiştir. K11 bu türden paylaşımların eğlence amaçlı olduğunu özgün ve etkili bir şekilde ifade etmiștir.

K13: Bu ileti doğru veya yanlış olabilir, bilemem. Ama şöyle de bir durum var ki iletinin doğru veya yanlışlığından daha önemli bence. Mesela bu kız kötü niyetli kişilerce töre cinayetine kurban edilmek için araniyor olabilir. Her insan iyi niyetle aranmaz ki öyle değil mi? O zaman bu kızın bulunmasına yardım ederek ona iyilik yapmış mı oluyoruz yani? Bence bilmediğimiz işlere karışmak doğru değil. Kayıpları bulmak polisin görevidir.

K40: Bu ilan bence doğru da olabilir yanlış da. Çünkü doğruluğunu veya yanlışlığını teyit etmeden bir yorum yapamam. Bu ilanı kendi duvarımda paylaşırım eğer doğruluğunu teyit etmişsem. Cü̈nkü ilan doğruysa yardım etmiş olurum kayıp olan kişsinin bulunmasına.

K11: Paylaşmam çünkü dalgasına yayıyorlar iște böyle șeyleri, sazan avı bunlar. Millet de inanıp paylaşıyor. Ne gereği varsa. Git resmi evrağın çıktısını al mühür bas çerçeveletip evinin duvarına as yani ne anlamı var, aynı șey:) Sanki Zuckerberg gelip madalya takacak ne günlere kaldık dönüp dolaşıp aynı şeyi sürekli paylaşıyorlar.

Kayıp ilanlarına ilişkin polis ve polise başvurma gereği vurgusu katılımcıların sıklıkla dile getirdiği bir durum olmuştur:

K1: Böyle bir ilanla karşılaştığımda polise haber verir görevimi yaparım. İlandaki telefon numarası aranmaz, güvenilir değil.

K12: Bu ilanı kendi duvarımda paylasmam çünkü özel şahıs numarası var ve bu tur kayıp ilanlarında 155 polisi arayın denir.

K67: Bu ilanı kendi duvarımda paylaşmam çünkü gerçek bir haber olsa "en yakın emniyet müdürlüğüne başvurun" gibi bir ibare kullanılır. Dolandırıcıların en çok kullandıkları yöntemlerdendir.

K18: Paylaşmam çünkü orda polise gidin denmemiş şahsi numara verilmiş doğru mu değil mi kesin değil

K113: Paylaşmam çünkü yalan bir bilgi de olabilir. Haber doğru olsaydı polisler kişinin kayıp olduğuna dair haberin yayılmasına izin vermezdi. 
Kayıp iletisi konusunda Medya Okuryazarlığı dersini almamış katılımcıların görüşleri çeşitlilik göstermekle birlikte, çok yönlü sorgulama yerine; yardım etme, kızın bulunmasına katkı sağlayabilme gibi duygusal nitelikteki çabaların ön planda tutulduğu görülmektedir.

K50: Bu ilanı kendi duvarımda paylaşırım çünkü birkaç kişiye ulaşmam bile fayda sağlayabilir.

K76: Gerçek olabilir çünkü kayıp ilanlarının önemli olduğunu düşünüyorum. Aynı şehirde yaşamıyorsak bu ilanı paylaşmam çünkü onu tanıyan biriyle tanışmıyorumdur.

K88: Bu ilanı kendi duvarımda paylașırdım. Çünkü bir șekilde bulunmasına benim de katkım olacağına inanırdım.

Bu ilanı kendi duvarımda paylaşırım çünkü olabildiğince insana ulaşması gerekiyor.

K97: Paylaşmam çünkü olayın sonucuna dair hiçbir zaman bilgi verilmez. Gerçek olduğu belli değildir. Belki kız bulunalı aylar olmuş olabilir ama bu görüntü döngüye girdiğinde herkes paylaştığından artık gerek kalmamış olabilir.

K17: Bu ilan bence önemli ama kendi duvarımda paylaşmam çünkü belki gerçek değil belki de tehlikeli bir şeyler barındırıyor.

Yukarıdaki öğrenci görüşleri incelendiğinde, katılımcıların Facebook iletilerini değerlendirirken genel duygusal bir yaklaşım içerisinde oldukları görülmektedir. Duygusal yaklaşıma ek olarak katılımcılar, ilk kez karşılaştıkları bir ileti karşısında sunulan sorunu hızlı bir şekilde çözme tutumu geliştirmektedir. Sorunu çözme tutumu geliștirirken katılımcılar bir an önce ellerinden geleni yapma, bir sorumluluk taşıdıkları düşüncesiyle sanal ortamda kısa sürede bu bilgiyi mümkün olan en çok sayıda kişiyle paylaşmayı bir başka deyişle, kısa sürede çok sayıda kişiyi durumdan haberdar etme yolunu seçmektedirler. Bu tutum bu türden paylaşımların Facebook vb. sosyal medya ortamlarında kısa sürede hızla nasıl yaygınlaştığını anlayabilmede önemli ipuçları sağlamaktadır. Konuya daha soğukkanlı yaklaşan katılımcılar ise iletiyi hızla paylaşıp yaymak yerine öncelikle konuyu derinlemesine anlama, çeşitli değişkenleri hesaplama ve olasılıklara bağlı olarak konuyu tekrar tekrar düşünüp değerlendirme gereği duymaktadır. Yukarıdaki bulgular, Medya Okuryazarlığında Beş Anahtar Soru yaklaşımını bilen ve iletilere yönelik farkındalığı oluşmuş öğrenciler ile henüz bu yaklaşımı bilmeyenler arasındaki yorum ve bakış açısı farklılıklarını göstermektedir.

Katılımcların yanıtları, Medya Okuryazarlığında Beş Anahtar Soru yaklaşımı çerçevesinde tema ve kodlara ayrılarak içerik çözümlemesiyle değerlendirilmiştir.

Tablo 7, beş aşamalı kuramsal yaklaşım çerçevesinde oluşturulan tema ve kodları göstermektedir. Tablonun soldaki ilk sütununda kuramsal çerçevenin tanımladığı, bir iletinin doğruluğunun anlaşılıp sorgulanmasında ileti içeriği ile ilgili olarak sorulması gereken sorular verilmektedir. Birinci soru iletinin kim tarafından oluşturulduğunu sorgulatan sorudur. Katılımcıların iletileri oluşturanın kimliğine ilişkin yanıtları kodlanarak bu soru kategorisine alınmıştır. Her iki ileti için de tema ve kodlar Beş Soru yaklaşımının aşamaları altında bu sorular ışığında gruplandırılmıştır.

İçerik çözümlemesinde katılımcıların verdiği yanıtlar kodlanarak temalar belirlenmiş ve temalar konunun açıklanmasında belirlenen kuramsal çerçeveye oturtulmuştur. Araştırmada benimsenen kuramsal yaklaşımın aşamalarına uygun olarak oluşturulan sistematik yaklaşımla, tematik yaklaşım ve kodlama sürecinde dağınıklığın önüne geçilerek pratiklik sağlanabilmiş, araştırmanın güvenirlik oranı bu sayede artırılmıştır. 
Tablo 7: Kuramsal Çerçeve Soruları, Temalar ve Kodların Tekrarlanma Sayıları

\begin{tabular}{|c|c|c|c|}
\hline $\begin{array}{l}\text { Medya } \\
\text { Okuryazarlığında } \\
\text { Beş Anahtar Soru } \\
\text { Kuramsal Temel }\end{array}$ & Tema & $\begin{array}{l}\text { Kod (f) } \\
\text { İleti 1: "Resmileşti dikkat!" }\end{array}$ & $\begin{array}{l}\text { Kod(f) } \\
\text { İleti 2: "Kayıp Aranıyor” }\end{array}$ \\
\hline $\begin{array}{l}\text { Bu iletiyi kim } \\
\text { oluşturdu? }\end{array}$ & $\begin{array}{l}\text { Sorumlu kimlik } \\
\text { Kişi } \\
\text { Kurum } \\
\text { Belirsiz }\end{array}$ & $\begin{array}{l}\text { Belli Değil (23), Prensipler } \\
\text { Genel Müdürlüğü (13), } \\
\text { MiT Müsteşarlığı (11), } \\
\text { Eğlenmek isteyen } \\
\text { öğrenci/genç (7), } \\
\text { Başbakanlık (7), Trol (6), } \\
\text { Tehlikeyi duyuran kişi } \\
\text { (5), Gizli (4), Yakınlarını } \\
\text { korumak isteyen (4), } \\
\text { Sosyal deney yapan kişi } \\
\text { (3), Emniyet güçleri (2), } \\
\text { Sivil polis (2), Duyarlı/ } \\
\text { düşünceli insan (3), } \\
\text { Facebook kullanmaya } \\
\text { yeni başlayan (2), Yaşlı } \\
\text { (2), Kuruntulu teyze (1) }\end{array}$ & $\begin{array}{l}\text { Kızın ailesi/yakınları (21), } \\
\text { Kötü niyetli kişiler (20), } \\
\text { Dolandırıcı (16) Telefon } \\
\text { numarasının sahibi (15) } \\
\text { Arkadaşları (14), Dalga } \\
\text { geçen/alay eden arkadaş } \\
\text { (12), Eğlence arayanlar } \\
\text { (7), Sınıf /okul arkadaşı (6), } \\
\text { Komşu (5), Duyarlı insanlar } \\
\text { (4), Kızın kendisi (1) }\end{array}$ \\
\hline $\begin{array}{l}\text { İletinin kaynağı } \\
\text { nedir/ ileti nereden } \\
\text { yönlendirilmiştir? }\end{array}$ & $\begin{array}{l}\text { İletiyi Yayan Kaynak } \\
\text { Belirsiz } \\
\text { Sosyal medya } \\
\text { Uydurma }\end{array}$ & $\begin{array}{l}\text { Bilinmiyor (38), Sahte } \\
\text { kaynak (13), Facebook } \\
\text { (11), Viral (7), Sosyal } \\
\text { medya (7), Ekşi Sözlük } \\
\text { (3), Duyarlı kaynak } \\
\text { (3), Öğrenci grupları } \\
\text { (3), İnci sözlük (2) }\end{array}$ & $\begin{array}{l}\text { Facebook/sosyal medya } \\
\text { (23), Belli Değil (19), } \\
\text { Web siteleri/Internet } \\
\text { (15), Kayıp ilanı afiş (11), } \\
\text { Kayıp Dernekleri (4) }\end{array}$ \\
\hline $\begin{array}{l}\text { Bu iletide benim } \\
\text { dikkatimi çekmek } \\
\text { için hangi teknikler } \\
\text { kullanıldı? }\end{array}$ & $\begin{array}{l}\text { Dikkat Çekici Öğeler } \\
\text { İnandırıcılık etkisi } \\
\text { Şüphe } \\
\text { Önlem }\end{array}$ & $\begin{array}{l}\text { Resmiyet (42), Sayılar } \\
\text { (37), Resmi kurum adları } \\
\text { (26), Tehlike vurgusu (23), } \\
\text { Tehdit gibi (21), Koruma } \\
\text { (12), Önlemini al (7) }\end{array}$ & $\begin{array}{l}\text { Fotoğraf (36), Telefon } \\
\text { numarası (23), Yardım } \\
\text { isteme (18), Endişe } \\
\text { vurgusu (14), Belirsizlik/ } \\
\text { bilinmeyen (11), Aciliyet } \\
\text { (6), Çaresizlik (5) }\end{array}$ \\
\hline $\begin{array}{l}\text { Başkaları bu iletiyi } \\
\text { benim anladığımdan } \\
\text { farklı olarak nasıl } \\
\text { algılıyor olabilir? }\end{array}$ & $\begin{array}{l}\text { Başkalarının Algısı } \\
\text { Doğru } \\
\text { Yanlış }\end{array}$ & $\begin{array}{l}\text { İnanırlar (23), Paylaşırlar } \\
\text { (21), Yayma (15), Duyurma } \\
\text { (13), Korunma (11), Yalan } \\
\text { (7), Yakınlarını korumak } \\
\text { isteği (7), Gereksiz } \\
\text { (5), Anlamsız (4) }\end{array}$ & $\begin{array}{l}\text { Bilmiyorum (24), Paylaşırlar } \\
\text { (13), Alay/Dalga (11), } \\
\text { Yayma (10), Duyurma } \\
\text { (9), Yardım etme gereği } \\
\text { (7), Gereksiz (5) }\end{array}$ \\
\hline $\begin{array}{l}\text { İleti neden } \\
\text { paylaşılmıştır? }\end{array}$ & $\begin{array}{l}\text { Paylaşma gerekçesi } \\
\text { Açık } \\
\text { Örtük } \\
\text { İyi niyetli } \\
\text { Kötü niyetli }\end{array}$ & $\begin{array}{l}\text { Bilgilendirme (16), } \\
\text { Korunma (11), Tehlikeyi } \\
\text { önleme (17), Trol (12), } \\
\text { Eğlence (11), Sosyal } \\
\text { deney (6), Dolandırıcılar } \\
\text { (5), Komiklik (3) }\end{array}$ & $\begin{array}{l}\text { Kızın çabuk bulunması } \\
\text { (36), Aileye yardım (21), } \\
\text { Trol (12), Dolandırıcılık } \\
\text { (11), Eğlence (6), Sosyal } \\
\text { deney (5), Töre cinayeti } \\
\text { için (4), Kızı afişe } \\
\text { etmek (3), Komiklik (2), } \\
\text { Dalga geçmek (2) }\end{array}$ \\
\hline
\end{tabular}

Tablo 7 incelendiğinde, birinci temanın iletiyi oluşturanın kim olduğunun sorgulanmasıyla ilgili olduğu görülmektedir. Kuramsal yaklaşımdaki ilk soru iletiyi oluşturanın kim olduğuyla ilgilidir. Bu nedenle veri çözümlemesinde belirlenen birinci tema, iletiyi oluşturanın kim olduğu konusundaki katılımcı yanıtları doğrultusunda şekillenmiştir. Kodlar ise bu temayı açıklayan katılımcı yanıtlarını göstermektedir. Parantez içinde verilen sayılar, kodların tekrarlanma sayılarını göstermektedir. Tablo 7'deki bulgulara göre "Resmilești Dikkat" başlıklı uydurma iletiyi oluşturan kişinin kimliğiyle ilgili soruya 23 katılımcı "belli değil” yanıtını vermiştir. Oysa ki 
ileti içeriğinde ileti sahibi olarak Prensipler Genel Müdürlügü işaret edilmekte ve 13 katılımcı iletiyi bu adı verilen kurumun yazdığına inanmış görünmektedir. MíT Müsteşarlığı'nın yazdığına inanan 13; iletinin Başbakanlıkça yazıldığını düşünen 7 katılımcı olduğu görülmektedir. İletiyi oluşturanın kimliği konusundaki tekrarlı görüşler iletinin doğru olduğunu düşünenler ile iletinin uydurma olduğunu düşünenlerin verdikleri yanıtların fark ve çeşitliliğine işaret etmektedir. Kurum/ kuruluş isimlerini verenler, iletinin doğru olduğuna inanırken; iletinin eğlence amaçlı paylaşıldığını, trol olduğunu, dolandırıcı iletisi veya yalan olduğunu düşünenler de mevcuttur. Kayıp iletisini oluşturanın kimliği konusundaki görüş, kayıp kızın ailesi ve yakınlarına yoğunlaşmıştır (Tekrar sayısı: 21). Kayıp ilanının kötü niyetli kişilerce oluşturulduğu düşüncesi ise 20 kez tekrarlanmıştır.

Birinci iletinin kaynağının belirsiz olduğu görüşü katılımcılar arasındaki hakim görüştür (Bilinmiyor yanıtının tekrar sayısı: 38). Kayıp iletisinin kaynağı ise birincil olarak so syal medya (23), ikincil düzeyde belirsiz (19) olarak görülmektedir. İletilenin inandırıcılık düzeyini güçlendirmek için katılımcılar birinci iletideki "Resmiyet" vurgusunun altını çizmişlerdir. Katılımcılara göre, birinci iletiyi dikkat çekici yapmak için ileti metninde resmi kurumların isimleri kullanılmıştır. Kayıp iletisine dikkat çekmek için ise fotoğraf kullanılması tekrarlı olarak dile getirilmiştir (Tekrar sayıları: 42 ve 36). İletilere dikkati çekmek için başvurulan diğer teknikler arasında sayılar ve telefon numarası kodlarının tekrar sayıları değerlendirildiğinde, katılımcıların dikkat çekici öğeleri sayı, vurgu ve kurum adları gibi belirgin kodlarla anlamlandırdığı görülmektedir. İletilerin başkaları tarafından nasıl algılandığı konusunda, öğelerin doğru anlama ve yanlış anlama temalarına göre değerlendirildikleri görülmektedir. Katılımcılar bir iletiyi anlamayı, iletinin doğruluğunu teyit etme ve yanlışlığını farketme üzerine kurgulamaktadır. Birinci iletide katılımcılar 23 kez başkalarının bu iletiye inanacağını tekralamıştır. İkinci iletideki hakim görüş ise 24 tekrar sayısı ile "bilmiyorum" sözcüğü olmuştur. Başkalarının iletileri nasıl anladığını bilmenin gereksiz olduğu, her iki ileti için de 5 kez tekrarlanmıştır. İletilerin niçin paylaşıldığı ve dolaşıma sokulduğu konusundaki katılımcı görüşleri ise açık-örtük olma ile iyi-kötü niyet doğrultusunda şekillenmiştir. İlk iletinin insanları bilgilendirme ve koruma amacıyla paylaşıldı̆̆ı görüşü 16 ve 11 tekrar sayılarıyla başı çekmiştir. İkinci iletinin paylaşılma nedeni olarak ise kızın çabuk bulunması en baskın görüş olarak 36 kez tekrarlanmıştır. Aileye yardım niyeti ise 21 kez tekrarlanarak katılımcıların bu tür iletileri paylaşmayı yardım etme tutumuyla ilişkilendirdiği görülmektedir.

Araştırmanın nicel boyutunda, farkın anlamlılığı testi ile katılımcıların medya okuryazarlığı dersini alma ve almama durumlarına bağlı olarak iletileri paylaşma davranışlarındaki değişim düzeyleri görülmektedir (Tablo 8). Burada medya okuryazarlığı dersini almış olan öğrenciler Beş Anahtar Soru yaklaşımını ders içi etkinliklerle uygulamalı olarak öğrenmiş ve bu yaklaşıma ilişkin kazanımları dönem sonunda başarıyla elde etmiş öğrencilerdir. Bu nedenle buradaki varsayım, medya okuryazarlığı dersi almış olanların iletileri sorgulamada belirli bir sistematik yaklaşımı kullanabileceğinden hareketle kullanmayanlara göre iletileri sorgulama ve paylaşmada farklılık oluşturacağıdır. Öğrencilerin iletileri paylașmaya karar verme durumları arasındaki fark, medya okuryazarlığı becerileri düzeyinde ölçülmemektedir. Paylaşma kararı, iletinin doğruluk ve güvenilirliğine ilişkin bir kanaat oluştuktan sonra alınmakta olduğundan dolayısıyla doğruluğundan şüphe duyulan iletiler paylaşılmayacak, güvenilir ve doğru olduğuna inanılan 
iletiler paylaşılacaktır. Buradaki ölçüm, öğrencilerin belirli bir ileti sorgulama yöntemini biliyor olmasının iletileri paylaşma kararı almada anlamlı fark oluşturup oluşturmadığını belirlemeye yöneliktir.

Tablo 8: Katılımcıların İleti1: "Resmilești Dikkat" ve İleti 2: "Kayıp Aranıyor" Paylaşma Karar Durumları ile Medya Okuryazarlı̆̆ı Dersini Daha Önce Lisans Düzeyinde Alma Durumlarına Göre t Testi Sonuçları

\begin{tabular}{|c|c|c|c|c|c|}
\hline & \multirow[b]{2}{*}{ Ders } & \multicolumn{2}{|c|}{ İleti 1} & \multicolumn{2}{|c|}{ İleti 2} \\
\hline & & $t$ & $\bar{p}$ & $t$ & $\mathbf{p}$ \\
\hline \multirow{2}{*}{ Paylaşım } & Aldı & \multirow{2}{*}{1,693} & \multirow{2}{*}{$0,041^{*}$} & \multirow{2}{*}{4,207} & \multirow{2}{*}{$0.000^{\star}$} \\
\hline & Almadı & & & & \\
\hline
\end{tabular}

Tablo 8'de katılımcıların iletileri paylaşma karar durumları incelendiğinde Medya Okuryazarlığı dersini almış olmanın, yani Medya Okuryazarlığında Beş Anahtar Soru yaklaşımını bilip uygulayabilmenin, her iki iletiyi paylaşma sürecinde anlamlı fark oluşturduğu görülmektedir. Medya okuryazarlığı dersini alan öğrencilerin almayanlara göre sosyal medyada karşılaştıkları iletileri daha iyi yorumlayıp derinlemesine anlamlandırarak daha üst düzey ve isabetli bir karar süreci işlettikleri görülmektedir $(\mathrm{p}<, 05)$. Resmileşti Dikkat başlıklı iletiyi sorguladıktan sonra iletinin uydurma olduğuna karar vererek iletiyi paylaşmama kararı vermede Medya okuryazarlığı dersini alanlar ile almayanlar arasında anlamlı bir fark oluşmuştur $(p=, 041)$. Kayıp Aranıyor iletisinde de katılımcılar iletinin doğruluğundan ve asıl paylaşanın niyetinden emin olamadıkları için paylaşmama kararı almada medya okuryazarlığı dersini almayanlara göre anlamlı farklılık göstermektedir $(p=, 000)$. Bu durum sosyal medyada karşılaşılan iletilerin medya okuryazarlığı eğitimi sayesinde daha doğru yorumlanabilmesinin mümkün olduğunu göstermektedir.

\section{Sonuç ve Öneriler}

$\mathrm{Bu}$ araştırmada, sosyal medyada sürekli tekrarlanan ve sık karşılaşılan uydurma veya doğruluğu şüpheli içeriği bireylerin sorgulama becerisi ile içeriği paylaşmaya karar verme süreçleri, Medya Okuryazarlığında Beş Anahtar Soru çerçevesinde ele alınmıştır. Medya Okuryazarlığında Beş Anahtar Soru yaklaşımı: (1) İçeriğin kim tarafından oluşturulduğu, (2) içeriğin kaynağı, (3) içeriği dikkat çekici kılmak için başvurulan teknikler, (4) başkalarının aynı içeriği nasıl anladığı ve (5) içeriğin niçin paylaşıldığını sorgulatan beș aşamalı kapsamlı bir yaklaşımdır. Bu yaklaşım, bireylerin karşılaştıkları sosyal medya iletilerine şüphe ve sorgulayan gözlerle bakmasını sağlamaktadır. Ayrıca bu yaklaşım, sahte içeriğin ayırdına varılmasında ve bilinçli sosyal medya kullanıcısı bireyler olmada bireylerin sorgulayıcı bilişsel süreçlerini harekete geçiren önemli bir yaklaşım olarak da değerlendirilebilir. Çalışma sonuçları, bu bakımdan medya okuryazarlığı eğitiminin doğrudan etkisi ile bireylerin sosyal medyada karşılaştıkları içeriğin inandırıcılık ve güvenirlik düzeyini sorgulama becerisini kuramsal çerçeve ile ele almıştır.

Çalışma sonuçlarına göre, Medya Okuryazarlığında Beş Anahtar Soru yaklaşımına göre iletileri sorgulayıp sosyal medyadaki içeriği anlamaya ve doğruluğunu belirlemeye çalışmak, iletileri anlamlandırmada bireylere katkı sağlamaktadır. $\mathrm{Bu}$ çalışmada medya okuryazarlığı dersini üniversite düzeyinde almış olan katılımcılar, Medya Okuryazarlığında Beș Anahtar Soru yaklaşımıyla sorulacak anahtar soruları, medya okuryazarlığı dersinin bir parçası șeklinde ders içi uygulamalarla önceden öğrenip uygulamış ve kazanım olarak edinmişlerdir (Bkz. katılımcıları belirleme 
ölçütleri). Medya okuryazarlığı dersini alanlar ile almayanların görüşleri ve iletileri değerlendirip sorgulama süreçleri bu bakımdan farklılık göstermiştir. Buradan hareketle, iletileri anlamlandırmada sistematik ve aşamalı bir sorgu sürecinin kullanılması, bireylerin sahte içeriği ayırt etme, iletileri derinlemesine sorgulayarak çok yönlü düşünebilme, iletilerle ilgili muhtemel olasılıkları öngörme ve iletileri ciddiye alıp almamaya karar verme noktasında bilişsel becerilerine olumlu katkı sağlayabildiği görülmektedir. Araştırma sonuçları, bir olgu olarak sahte içerik paylaşımının iletiyi oluşturan kişi (kaynağı belirsiz, resmi bir kurum), iletinin paylaşılma gerekçesi (yardım talebi, uyarı, eğlence), iletinin inandırıcılığını artırmak için başvurulan teknikler (resmiyete vurgu, telefon numarası, belge veya karar sayısı kullanılması) ve iletiye ilişkin başkalarının algısı (inanırlar, inanmazlar) ile açıklanabildiğini göstermektedir.

Medya Okuryazarlığında Beş Anahtar Soru Yaklaşımı, medya okuryazarı bireylerin yetiștirilmesinde yıllarca süren uzun soluklu deney, uygulama ve araştırmalardan süzülerek kavramsallaştırılmış önemli bir sistematik yaklaşım olarak alanyazındaki yerini sağlamlaştırmış önemli bir rehber niteliğindedir. Medya Okuryazarlığında Beş Anahtar Soru yaklaşımına göre sosyal medya iletilerini sorgulama ve anlamlandırma konusunda Türkçe alanyazın incelendiğinde herhangi bir ders içi uygulamalı araştırma bulgusuna rastlanmamıştır. $\mathrm{Bu}$ yaklaşımın anlatıldığı tek Türkçe başlıca kaynak eserin ise, Thoman ve Jolls'un (2008) kaleme aldığı ve içinde derslerde kullanılabilecek çeşitli etkinlik planlarının bulunduğu asıl kaynak kitabın Türkçe çevirisi ${ }^{4}$ olduğu görülmektedir. Öğrencilerin medya iletileri konusunda kendi bireysel anlamlandırma süreçlerini işleterek anlam yapılandırması ve içerik konusunda eleştirel sorular sorabilmeleri için medya okuryazarlığının temel ilkeleri kapsamında oluşturulan bu beş anahtar soruya odaklanmak önemlidir. Böylece medya okuryazarlığı alanındaki eğitimciler, uygulamalı bir sorgulama süreci kullanarak, öğrencilere bir iletinin içeriğini veya güvenirlik düzeyini sorgulamayı öğretebilmektedir (Share ve Thoman, 2007: 13).

Facebook vb. sosyal medya ortamlarındaki paylaşımların doğruluğunun sorgulanmadan gerçekmiş gibi sunulması ve bu iletilerin çok farklı eğitim-kültür düzeyindeki kimselerce benimsenerek defalarca paylaşılıyor olması medya okuryazarlığının bu süreçte öğrenilebilir ve öğretilebilir bir düşünsel beceri olabileceği fikrini vermektedir. Deveci ve Çengelci çalışmasında (2008) katılımcıların medya okuryazarlığını eleştirel düşünme becerisi ile ilişkilendirerek tanımladığına işaret etmektedir. Eleştirel düşünme becerisi, iletişim ve öğrenme bağlamında, karşılaştığımız her türden içeriği değerlendirip sorgulamada, içeriği anlamlandırarak içeriğe ilişkin karar süreçlerini etkin şekilde işletebilmemizde en önemli paya sahip 21. yüzyıl becerilerinden birisi olarak değerlendirilmektedir. Bir başka çalışmada katılımcılar medya okuryazarlığını bir gereklilik olarak değerlendirmiş ve üniversite düzeyindeki öğrencilere bu dersin mutlaka okutulması gerektiğini söylemişledir (İnan, 2010). Bu çalışmada elde edilen sonuçlar, bu görüşün doğruluğunu desteklemektedir. Atmaca (2016) çalışmasında medya okuryazarlığı dersini alan ve almayan katılımcıların medya okuryazarlığı konusundaki ifadelerinde kullandıkları toplam sözcük sayılarını karşılaştırmıştır. Karşılaştırmalı bir araştırma olması ve medya okuryazarlığı dersini alanların almayanlara göre daha derinlemesine düşünerek daha çok sayıda sözcük kullanarak detaylı değerlendirmeler yapabildiklerini göstermesi bakımlarından Atmaca'nın araştırması bu araştırma sonuçlarıyla örtüşmektedir. 
Medya ve dijital ortamlar aracılığıyla karşılaştığımız içerik yığınlarının çeşitliliği ve içeriği üretenlerin asıl niyetleri açısından baktığımızda ise her bireyin kendi bilişsel süreçleri kapsamında kapsamlı ve derinlemesine sorgulama becerileriyle donanması gerekmektedir. Medya okuryazarlığının öznesi bireydir. Çünkü diğer tüm okuryazarlıklar gibi medya okuryazarlığı da bireysel bir beceri olup bilişsel yaklaşımlarla açıklanabilen bir çözümleme ve anlamlandırma sürecinin geliştirilmesiyle, süreç içinde yapılandırılan kazanımlarla her türden ileti ve içeriği sorgulayarak çok yönlü şekilde anlamlandırılabilme becerisinin yerleşik hale getirilmesini ifade etmektedir. McLuhan (1967) henüz internet ve sosyal medya yokken ortaya attığı görüșleri ve geliştirdiği kuramsal yaklaşımıyla medya ve ileti ilişkisini açıklamıştır. McLuhan'ın dönemindeki medya teknolojileri ile günümüz teknolojileri arasında büyük farklılıklar bulunmasına karşılık, medyanın işlevi ve medyadaki içeriğin oluşturulup yayılma mantığının aynı kaldığı görülmektedir.

Bir araç olarak, teknolojilerin şekli değişime uğrayıp farklılaşmaya devam edecek ancak insanoğlunun kendi duygu ve düşüncelerini iletiler yoluyla yayma çabası aynı kalacaktır. Dolayısıyla McLuhan'ın ortaya attığı görüşler ele alındığında medya-ileti ve içeriği anlamlandırma becerisi ilişkisinin asıl önemli konu olduğu ve buna bağlı olarak medya okuryazarlığının her zaman konunun en önemli boyutunu oluşturmaya devam edeceği söylenebilir. Televizyonda yayımlanan bir sahte haber ile, Facebook üzerinden dolaşıma sokulan bir sahte iletinin oluşturulma ve paylaşılma amacı aynıdır. Buradaki değişim, yalnızca medya teknolojisinin kendisinde yaşanmakta fakat bireylerin iletiyle ilk karşılaştıklarında izlemeleri gereken yol aynı kalmaktadır. Teknolojinin gelişimine bağlı olarak içerik yoğunluğu ve sorgulanması gereken iletilerin sayısı artmış, bu bakımdan insanların işi gün geçtikçe zorlaşmıştır. Jolls (2007), iletileri anlamaya çalışırken genel önerme tümcelerini kullanmak yerine doğrudan sorular sorarak süreci daha dinamik ve etkili hale getirebilecek çözümü üretmiştir.

Dijital çağda iletişim ortamlarının yaşadığı dönüşüme bağlı olarak, günümüzde medya okuryazarlığı becerisine sahip olmak; demokratik katılım, bilinçli ve etkin bireyler olma ve sosyal entegrasyonun önemli bir parçası olarak değerlendirildiğinden her bireyin medya okuryazarlığı eğitimi almasının önemi sürekli olarak vurgulanmakta ve bu durum ihmal edilmemesi gereken bir süreç olarak günden güne daha da önem kazanmaktadır. Ülkelerin kendi dinamikleri doğrultusunda kendi medya okuryazarlığı eğitim programlarını hazırlayıp başarıyla uygulamaları önemlidir.

Günümüzde medya okuryazarlığını, bütüncül yaklaşımla ele alıp dijital gelişmeler doğrultusunda sürekli yenilenip şekillenen ve yaşamboyu devam eden bir beceriler bütünü olarak değerlendirerek öğrenme ortamlarına uyarlamak gerekmektedir. İçeriği üretmek kadar üretilmiş içeriği sorgulayıp sosyal mecralarda dolaşımına katkı koymak veya koymamak da sosyal medyadaki roller açısından önem taşımaktadır. İçeriğin çeşitli amaçlar doğrultusunda mutlaka kurgulanmış ürünler olduğundan hareketle, bireylerin iletilerin kurgusallığının bilincinde olarak doğru karar süreçlerini işletebilmeleri, yeni medya okuryazarlıklarını etkin kullanabilme becerisinin temel ölçütleri arasındaki yerini korumaktadır.

Sonraki araștırmalarda, bu çalışmada kullanılan iletileri sorgulama yöntemi farklı yaş grupları üzerinde uygulanarak daha kapsamlı sonuçlar elde edilebilir. Verdegem (2014)'in çalışmasında belirttiği, iletileri sorgulamada medya okuryazarlığında 
sahip olunması gereken stratejik, analitik, bilgiye dayalı ve duyuşsal becerileri ayrı ayrı inceleyerek ilişkilendiren uygulamalı çalışmaların farklı yaş grupları üzerinde beceriler temelinde denenerek yapılması alanyazına katkıyı geliştirecektir.

\section{Notlar}

${ }^{1}$ Asıl çalışmada geçen concept sözcüğüyle, sözcüğün sözlükteki ilk anlamı olan kavram sözcüğü kastedilmediğinden, burada sözcüğün Türkçe karşılığı olarak, diğer anlamı olan düşünce sözcüğü kullanılmıştır.

2 (Miles ve Huberman, 1994:73; Patton, 2002:124).

3 Öğrencilerin yazılı görüşleri; öğrencilerin kendi yazım dili, noktalama işareti kullanımı ve ifade biçimleri korunacak şekilde aslı hiç değiştirilmeden araştırma metnine aynen alınmıştır. Buradaki amaç, öğrencilerin duygu durumunu ifade ederken benimsediği yolu değiştirmeden araştırmaya aktarabilmektir.

4 21. Yüzyıl Okuryazarlığı: Medya Okuryazarlığına Genel Bir Bakış ve Sınıf İçi Etkinlikler. Tessa Jolls, Elizabeth Thoman (Çev: Cevat Elma ve Alper Keskin).

\section{Kaynakça}

Altun, A. (2014). Medya Okur Yazarlığı Eğitimine Yönelik Türkçe Yayınlar: Bir Bibliyografya Denemesi. ODÜ Sosyal Bilimler Araştırmaları Dergisi (ODÜSOBİAD), 4 (9), 5-15.

Atmaca, Ç. (2016). Medya Okuryazarlığı Dersinin Öğretmen Adayları Üzerindeki Etkileri. Ege Eğitim Dergisi, 17 (2), 442-480.

Babad, E., Peer, E., hobbs, R. (2102). Media Literacy and Media Bias: Are Media Literacy Students Less Susceptible to Nonverbal Judgment Biases? Psychology of Popular Media Culture, Vol 1(2), 97-107.

Bacaksız, T. (2010). Medya Okuryazarlığı Dersinde Gazete ve Dergi kullanımı: İzmir'de Medya Okuryazarlığı Dersinin Öğrencilerin Gazete Ve Dergi Okuma Alışkanlıklarına Olan Etkisi. (Yayımlanmamış yüksek lisans tezi).

Creswell, J. W. (2007). Qualitative Inquiry and Research Design: Choosing Among Five Approaches. Thousand Oaks, CA, US: Sage Publications, Inc.

Desmond, R. (1996). (Ed. Flood, J., Heath, S. B. And Lapp, D.). TV Viewing, Reading and the Media Literacy. Handbook of Research on Teaching Literacy Through the Communicative and Visual Arts. A Project of the International Reading Association, New York.

Deveci, H., ve Çengelci, T. (2008). Sosyal Bilgiler Öğretmen Adaylarından Medya Okuryazarlğına Bir Bakış. Yüzüncü yıl Üniversitesi Eğitim Fakültesi Dergisi, 5(2), 25-43.

Duncan, B. et. al. (1989). Media Literacy Resource Guide. Ministry of Education and the Association for Media Literacy, Toronto.

Durak, H. \& Seferoğlu, S. S. (2016). Türkiye'de Sosyal Medya Okuryazarlığı ve Sosyal Ağ Kullanım Örüntülerinin İncelenmesi. Uluslararası Sosyal Araştırmalar Dergisi, 9(46), 1-10.

Elitok Kesici A. Kızılkaya, A. (2016). Medya Okuryazarlğı Dersine İlişkin Öğretmen Görüşleri. Eğitim Teknolojisi Kuram ve Uygulama, 6(2), 174-189.

Giorgi, A. (1997). The Theory, Practice and Evaluation of the Phenomenological Method as a Qualitative Research Procedure. Journal of Phenomenological Psychology, 28 (2), 235-260. 
İnan, T. (2010). Öğretmen Adaylarının Medya Okuryazarlık Düzeyleri ve Medya Okuryazarlığına İlişkin Görüşleri. (Yayımlanmamış yüksek lisans tezi). YÖK Ulusal Tez Merkezi.

Jenkins, H. (2006). Convergence Culture: Where Old and New Media Collide. New York: New York University Press.

Jolls, T. (2007). An Overview and Orientation Guide for Media Literacy Education, Los Angeles, Center for Media Literacy.

Jolls, T., (2018). Center For Media Literacy. http://www.medialit.org/media-literacydefinition-and-more Son erişim tarihi: Kasım 2018

Keller, U. (1995). Qualitative Data Analysis: Theory, Methods and Practice for Researchers. London: Sage.

Masterman, L. (1980). Teaching About Television. Palgrave.

Masterman, L. (1985). Teaching the Media. Comedia Publishing Group.

McLuhan, M. \& Quentin F.(1967). The Medium is the Massage. Bantam Books.

Merriam, S. B. (1998). Qualitative Research and Case Study Applications in Education. San Francisco, CA 94104.

Miles, M., B., \& Huberman, A., M. (1994). Qualitative Data Analysis: An Expanded Sourcebook. Thousand Oaks, CA, Sage.

Moustakas, C., E. (1994). Phenomenological Research Methods. Thousand Oaks, CA, Sage Publications.

Önal, H., İ. (2016). Medya Okuryazarlığının Topluma Getirdiği Yenilikler. Medya Okuryazarlığı (Ed. Küçük Durur, E.) içinde ss.179-195. Siyasal Kitabevi, Ankara.

Patton, M., Q. (Qualitative Research and Evaluation Methods. London. Sage Publications.

Poggenpoal, M., \& Myburgh, C. (2003). The Researcher as Research Instrument in Educational Research: A Research Instrument. Education, 124, 418-421.

Potter, W., J. (2004). Theory of Media Literacy: A Cognitive Approach. Thousand Oaks, CA, Sage.

Potter, W., J. (2005). "Media Literacy”. Sage, London.

Real, Y., M. (2008). "An Assesment of the Relationship Between Creativity and Informationand Media Literacy Skills of Community College Students for a Selected Major". PhD Dissertation, Malibu, USA.

Shenton, A. (2004). Strategies for Qualitative Research Projects. Education for Information, 22, 63-75.

Share J. \& Jolls, T. \& Thoman E. (2019). Five Key Questions That Can Change The World. Son Erişim Tarihi: Şubat 2019, https://www.medialit.org/readingroom/five-key-questions-can-change-world

Thoman, E. (1993). Skills and Strategies for Media Education. Erişim Tarihi: Ekim 14, 2018. http://www.medialit.org/reading-room/skills- strategies-mediaeducation 
Thoman, E. (1998). Media Literacy: A Guided Tour of Selected Resources for Teaching". The English Journal. 87 (1), pp. 34-37.

Thoman E. \& Jolls, T. (2008). Literacy for the $21^{\text {st }}$ Century. An Overview \& Orientation Guide to Media Literacy Education. Center for Media Literacy, Canada.

Willig, C. (2012). Perspectives on the Epistemological Bases for Qualitative Research Methods.

Vanwynsberghe, H., Verdegem P. (2013). Integrating Social Media in Education. ClCWeb-Comparative Literature and Culture 15(3): Article 10.

Vanwynsberghe, Paulussen \& Verdegem (2014). Towards A Conceptual framework for Media Literacy. 1-19.

Yıldırım, A., ve Şimşek, H. (2005). Sosyal Bilimlerde Nitel Araştırma Yöntemleri. 5. Baskl, Ankara. 